\title{
Shared Reading Implementation During the Literacy Period of a Child with Hearing Loss
}

\section{H. Pelin Karasu*}

\begin{abstract}
Shared reading, which enables children to acquire new experiences in the field of language, is one of several fundamental instructional practices that facilitate the development of literacy skills in children from an early age. This descriptive and holistic case study aims to investigate the shared reading practices carried out in the Primary 1st Grade literacy studies. The subject of the study is a child with hearing loss who receives auditory-oral education. The data in this study have been collected through the syllabus, classroom observations, documents, the records of the validity and reliability committee, process products and the researcher's log. In the analysis of the data, the educational program and the process products have been examined, observation sessions of shared reading practices have been documented, and prominent findings have been identified. It could be safely claimed, per the findings of this study, that the features of the storybook, the literacy strategies applied during shared reading practices, and the follow-up activities contribute significantly to the benefits of shared reading practices.
\end{abstract}

\author{
Keywords: \\ Child With Hearing Loss, Teacher-Child Interaction, \\ Shared Reading, Reading Strategy, Cochlear Implant
}

\section{Introduction}

Teaching literacy is a long-term process consisting of instructional practices aiming at the analysis of the reciprocity between phonemes and graphemes, and the structuring of the meaning of a text. This is mainly because the development of literacy skills in children starts well before formal education in literacy and extends over the years. (Miller, 2005). Children develop an awareness about the transmissibility of thoughts through writing by establishing a connection between spoken and written language in the pre-school period. During this period, their vocabulary expands rapidly. They start recognizing symbols, and they attend to the phonemes and graphemes they see around them. Thus, the child already has a significant understanding of the phonemes of the language at the beginning of formal reading education. With instructional practices the child starts integrating this knowledge with printed letters, and establishing a letter-sound relationship (Justice, 2006). The success of formal reading education is directly linked 
to the experiences acquired in the pre-school period. Therefore, it is necessary that the child is exposed to instructional practices that reinforce the development of language skills, help to understand and interpret events, and facilitate establishing relationships before formal reading education and during the first reading education (Druten-Frietman, Strating, Denessen, \& Verhoeven, 2016). Shared reading (SR), as one of these practices, contributes to the development of listening comprehension, use of the language input in a variety of contexts, and the structuring of meaning (Hudson \& Test, 2011). This study investigates the SR practices carried out with a child with hearing loss at Primary 1st Grade.

SR is an interactive story reading practice in which the teacher reads a text to the students either individually or in small groups, and the students participate as listeners and actively talk about what they listen to (Hudson \& Test, 2011). In the literature, practices in which an adult reads a story to a child is referred to by a variety of names such as shared reading, interactive reading and dialogic reading. Some sources contend that these activities serve the same purposes and there are just minor differences among them (Blachowicz \& Fisher, 2007). Dialogic reading is carried out in a way that enables the adult to ask the child questions about the target vocabulary while the adult and the child share the book. Similarly, in interactive reading, an adult reads a story to a child and asks questions while the target vocabulary is accentuated via the pictures in the story (Trussell, 2018). Terms such as "read alouds," "repeated storybook reading," "story-based lesson" and "literacy-based lesson" are frequently used in the literature on SR (Hudson \& Test, 2011). In SR, the teacher reads the story aloud, guides the children to make sense of what they listen to, and points out to the structure, the sequence and the relationships among the events in the story by asking questions. New vocabulary is automatically used in the natural flow of this practice (Lederberg, Miller, Easterbrooks, \& McDonald-Connor, 2014; Zucker, Justice, Piasta, \& Kaderavek, 2010).

SR is one of the fundamental instructional practices that ensure interaction, scaffolding and acquisition of new experiences concerning the language. SR practices have four essential features: (a) storybooks are read multiple times at intervals, (b) the children are encouraged to take part in the activity, retell the stroy that they have listened to, and make predictions, (c) the teacher asks questions, shares the answers with the students, provides feedback to students' responses and acts as a model for the use of language, and (d) the content of the book is in line with the children's needs in terms of language, knowledge and experiences. These features enable the students to understand the structure of written texts, improve listening comprehension, develop phonetic awareness and expand their vocabulary (Druten-Frietman, et al., 2016; Lonigan, Purpura, Wilson, Walker, \& Clancy-Menchetti, 2013; Strasser, Larrain, \& Lissi, 2013). The comprehension of the story by a child with hearing loss depends on the features of the story and the instructional strategies that the teacher employs in SR. Instructional strategies such as using predictable texts to retell the story, showing through pictures, expanding opportunities to participate, establishing relationships, and making inferences improve children's sight-word knowledge and increase their awareness of reading fluency (Falk, Di Perri, Howerton-Fox, \& Jezik \& 2020).

Follow-up activities are practices that facilitate retention and reinforcement of the knowledge and experience shared with the child while offering the child the opportunity to make attempts to use the language. Crafts, dramatisation, task cards and freewriting activities can be used as immediate follow-up activities after SR. Some studies highlight the contribution of SR practices to the development of print awareness (e.g. Spencer, Goldstein, \& Kaminski, 2012; Evans, \& Saint-Aubin, 2013). The adult's and the child's focus, and verbal or visual direction of the child's attention to print during SR are important for the development of print knowledge (Piasta, Justice, McGinty, \& Kaderavek, 2012). A variety of techniques can be employed to direct and intensify the child's attention to print in SR practices. These techniques may take verbal or non-verbal forms. For instance, the child's attention can be verbally directed to print by talking about what is written in the story or, nonverbally, the child can be shown the print while reading. Piasta et al. (2012), in their longitudinal study with 4-year-olds, have applied SR for thirty weeks and directed the children's attention to print both verbally and nonverbally. In the two years that followed, a significant improvement was observed in the word reading and comprehension skills of the children whose attention was directed to print.

Majority of the literature on the application of SR practices on children with hearing loss in the school environment has been carried out in the pre-school period, with some of the studies focusing on the children's participation (Williams \& McLean, 1997; Gioia, 2001), and vocabulary teaching (Trussell, \& Easterbrooks, 2014), while others on the strategies employed and early literacy skills (e.g. DesJardin et al., 2014; Werfel, Lund, \& Schuele, 2015). Williams and McLean (1997) studied the participation of kindergarten students in SR group practices and observed that the participation patterns in these activities were similar for children with and without hearing loss and that SR increases the participation of children with hearing loss. Similarly, a study by Gioia (2001) demonstrates that children with hearing loss manage to retell the 
story and participate more and more in the activity in each subsequent lesson provided that their active participation is ensured and also that the materials are chosen in accordance with their recipient and expressive language skills. Furthermore, Trussel and Easterbrooks (2014) studied the effect of SR practices on vocabulary learning of children who use the sign language and studied the effect of SR practices on vocabulary learning of children who use the sign language and concluded that these practices facilitate vocabulary learning. Desjardin et al. (2014) investigated the strategies that adults used during SR and found out that adults who work with children with hearing loss used the strategies of labelling, showing through pictures, improving participation, expecting predictions, and summarizing more frequently than their counterparts who work with hearing children. This was explained to be an indication of the higher intensity of the language skills needs of children with hearing loss compared to their hearing peers. Werfel et al. (2015) compared the early literacy skills of children with hearing loss to those of their hearing peers and found no significant difference in terms of the alphabetical knowledge but observed a latency on behalf of the children with hearing loss in the print and vocabulary knowledge. All researchers agree that SR practices support the children with hearing loss in the areas that they have difficulty in, and underline the need to apply these activities in a systematic and organised way.

Presently, there is only one study in Turkey that has investigated SR practices on children with hearing loss. In the above mentioned study, Girgin (2013) investigated the SR practices applied to children with hearing loss in the Primary 1st Grade auditoryoral education and determined the strategies used. Findings of the study point out that multiple readings and use of reading strategies support the structuring of meaning and help children adopt these strategies. No other study that focuses on the time allocated to shared reading practices, the stages of the practices, and the use of writing experiences in the follow-up activities has been carried out with children with hearing loss in an educational environment in which the auditory-oral approach is applied.

SR facilitates the development of oral language skills of children with hearing loss in educational environments where the auditory-oral appraoch is applied. SR activities make it possible for the children to listen to a story read aloud by an adult, to talk about the events in the story, and to ask and answer questions (Girgin, 2013). Moreover, these activities provide opportunities for children to expand their vocabulary range and establish relationships between thoughts, events and print. Thanks to these benefits, SR is considered among the best practices and evidence-based practices that have an important role in special education. Another reason for this is the fact that the contribution of SR to the improvement of language and academic skills of children has been documented through both quantitative (experimental, quasiexperimental, single subject, correlation researches) and qualitative research (Hudson \& Test, 2011).

The recent advances in the field of hearing aids technology and cochlear implants have aroused expectations that children with hearing loss can acquire listening and speaking skills on their own like their hearing counterparts. However, the benefits of these developments concerning hearing aids depend largely on early diagnosis, early education and the quality of the educational environment. In addition to the qualities that enable the child with hearing loss to understand a story that he listens to, the requirements that will allow him to benefit from SR practices in an educational environment where the auditory-oral approach is applied will be demonstrated as an outcome of this study. It is believed that the findings of this study will guide the teachers who work with children with hearing loss in SR practices, draw attention to the significance of $S R$, and contribute to the literature in the feld. This study aims to investigate SR practices carried out in the Primary 1st Grade literacy lessons. Accordingly, it aims to answer questions such as (1) how the storybooks were designed in SR practices, (2) how SR was implemented, and (3) how the SR practices were integrated to writing experiences.

\section{Method}

A descriptive and holistic single case design model has been used in this study to investigate the SR implementation process. In a descriptive case study, it is imperative that a phenomenon is clearly described and conceptualised. Such case study models require outlining the phenomenon in question in the first place. This study also involves a detailed analysis of the SR practices as a whole. In this respect, this study is a holistic single-case design. (Yin, 2009).

\section{Educational Environment}

The study was carried out in the Education and Research Center for Hearing Impaired Children (ICEM), founded in 1979 as part of Anadolu University. ICEM is a research and application center which offers children with hearing loss full-time day education based on the auditory-oral approach at the preschool, primary, and middle school levels as well as early provision of hearing aids and tracing their audiological development. At ICEM, the children receive three years of pre-school education, in addition to 4 years of primary and 4 years of middle school education. 
Besides, ICEM offers reverse inclusion programs in preschool education so that children with hearing loss attend school with their hearing peers in natural and structured environments to improve their academic and social skills. At primary and middle school levels, the children are enrolled in the state school next to the center for inclusion and are given support education services by ICEM. Literacy studies are based on the whole language approach in the pre-scool period and the balanced literacy approach at the primary school level.

\section{Participants}

During the course of this study, there were 8 children with hearing loss at the Primary 1st Grade in the 20142015 academic year. The study focused on a child who was diagnosed with hearing loss (at the age of 34 months) and started using a hearing aid (at the age 35 months) at what is considered to be a late age. He started pre-school when he was 52 months old without ever receiving early intervention programmes (pseudonym Tan). The underlying reason for the choice of this subject is the interest in how a child with hearing loss who was introduced to auditory input late in his life would participate in the SR practices in an educational environment in which the auditoryoral approach was used. Tan, who recevied two years of pre-school education at ICEM before primary school, is 6 years 4 months old and he underwent a cochlear implant operation when he was 40 months old. His average hearing loss in the left ear is $98 \mathrm{dBHL}$. His parents are primary school graduates; the mother does not work and the father is a seasonal worker. Tan has a brother who is three years older and has no hearing loss. In the Primary 1st Grade, group lessons and one-on-one sessions are carried out by two teachers who have studied Teaching Children with Hearing Loss. One of the teachers have 20, and the other one has 14 years of practical experience in working with children with hearing loss. The researcher has been working on the improvement and assessment of the literacy skills of children with hearing loss for 24 years.

\section{Data Sources and Procedures}

As part of a longitudinal approach, this study focuses on the SR practices carried out in the Primary 1st Grade in the 2014-2015 academic year. Data collection techniques applied in the study include the curriculum and the instruction programs, in-class observations, documents, records of the validity and reliability committee meetings, process-products and the researcher's log. The Turkish Course program planned in accordance with the Social Studies Course in the Primary 1st Grade, the storybooks chosen for the SR practices and the modifications on these books, participation of the child in these practices as a group member and the process-products including task cards and freewriting texts have also been taken into consideration.

\section{Data Analysis Process}

The analysis of the qualitative data is inductive in nature. Detailed data sets constitute general categories (Creswell, 2005). Accordingly, storybooks used in SR practices were analyzed, classroom observations of the practices were documented and prominent traits have been highlighted after a thorough examination of the process-products. Four themes have emerged as a result of this process: (a) the design of the storybook, (b) reading of the story and retelling it, (c) direction of story telling and question answer sessions, and (d) the writing experience.

\section{Trustworthiness and Validity}

To ensure credibility in the study, a variety of data collection techniques were employed, the research process was monitored, collection and analysis of the data were carried out systematically, the extensive amount of data collected was verified by a validity and reliability committee. Two experts were involved in the validity process and 6 validity meetings were held in the 2014-2015 academic year.

\section{Ethics}

Informed consent of Tan's family, teachers and the research center was obtained for this study, which is part of a longitudinal study in which SR practices in Primary 1st Grade were investigated.

\section{Results}

\section{Prominent Traits Have Been Documented Below}

How were the storybooks designed in the SR practices?

The subjects in the curriculum, dates of implementation and the names of the storybooks used in SR practices are presented in Table 1.

As seen in Table 1, a total of 36 storybooks were read in class as one story for each weekly topic in the curriculum. Every week, other than the four-day ones that coincided with the holidays on the Republic Day and the New Year, consisted of five school days on which the same story was read. Specifics of the design of the storybooks used in SR have been given below.

The stylistic features of the book not only make it easier for the reader to understand but also increases the motivation to read (Machado, 2007). On the cover of the books, are pictures depicting the main 
Table 1

Subjects in the Curriculum, Dates of Implementation, and the Names of the Story

\begin{tabular}{|c|c|c|}
\hline Subject & Date & Story Book \\
\hline Holiday & 15-19 September 2014 & Cemile Learns to Swim \\
\hline Our school & 22 September-03 October 2014 & $\begin{array}{l}\text { Cemile Goes to School } \\
\text { Atakan Starts School }\end{array}$ \\
\hline The City That We Live In & 06-17 October 2014 & $\begin{array}{l}\text { Gülenay and the Little Duck } \\
\text { Yasemin in the Patisserie }\end{array}$ \\
\hline Our Home and Family & 20-24 October 2014 & Atakan Stays with his Grandma \\
\hline The Republic Day & 27-31 October 2014 & Long Live the Republic \\
\hline Vehicles & 03-14 November 2014 & $\begin{array}{l}\text { Gülenay and the Little Puppy } \\
\text { Gülenay and the Little Pony }\end{array}$ \\
\hline Autumn & 17-21 November 2014 & Atakan Goes to the Playground \\
\hline Cleanliness & 24 November -05 December 2014 & $\begin{array}{l}\text { Cemile Wears her New Boots } \\
\text { Sleepyhead Kimi }\end{array}$ \\
\hline Winter & 08-12 December 2014 & Kimi Who Doesn't Like Bathing \\
\hline Balance & 15-26 December 2014 & $\begin{array}{l}\text { Curious Kimi } \\
\text { Ayben at the Circus }\end{array}$ \\
\hline The Calendar and the New Year & 29 December 2014-02 January 2015 & The Christmas Tree \\
\hline What Do We Wear And When & 05-23 January 2015 & $\begin{array}{l}\text { Gamze and her Nephew } \\
\text { Kimi on the Way to School }\end{array}$ \\
\hline Hot-Cold & 09-13 February 2015 & Gamze at her New House \\
\hline Natural Disasters & 16-20 February 2015 & Snowstorm \\
\hline Traffic and Safety & 23 February -06 March 2015 & $\begin{array}{l}\text { Gamze and her New Dog } \\
\text { Hande and her Dog on the Train }\end{array}$ \\
\hline Solid-Liquid & 09-13 March 2015 & Yasemin and her Little Visitor \\
\hline Animals we Eat & 16-27 March 2015 & $\begin{array}{l}\text { Gamze by the Lake } \\
\text { Yasemin and Karbeyaz }\end{array}$ \\
\hline Wool-Leather-Silk & 30 March -03 April 2015 & Elif at the Farm \\
\hline Spring & 06-17 April 2015 & Gamze and her Kite Gamze in the Garden \\
\hline April 23rd Children's Day & 20-24 April 2015 & Cemile Loves her Friend Dearly \\
\hline Shopping & 27 April -08 May 2015 & $\begin{array}{l}\text { Elif Cooks Pizza } \\
\text { Atakan Goes to the Supermarket }\end{array}$ \\
\hline Plants around Us & 11-22 May 2015 & $\begin{array}{l}\text { Yasemin at the Camp } \\
\text { Gülenay out for a trip to the Countryside }\end{array}$ \\
\hline Youth and Sports Day & 25-29 May 2015 & Yasemin in the Balloon Fest \\
\hline National Days & 01-05 June 2015 & Cemile Won't Share her Toys \\
\hline Summer & 08-12 June 2015 & Cemile Goes on a Holiday \\
\hline
\end{tabular}

characters and events in the stories in addition to the names of the books. There are also colorful and clear illustrations in the books about the events in the story. Features of these books concerning the structuring of meaning have been categorized as per (a) propriety for the curriculum, (b) relationships between events, (c) relationships between the story and the illustrations and $(d)$ readability of the text.

(a) Propriety for the curriculum. The themes of the stories to be used in SR practices need to be appropriate for the age, language skills and knowledge experience of the children. Choosing books that the children can relate to using their own experience plays an important role in their structuring of the meaning of the events (Girgin, 2013; Miller, 2005). It was observed in this study that the themes in the storybooks displayed a certain congruency with the curriculum that equips the children with new information and experience. The vocabulary used in the Social Studies Course was also used in meaningful contexts repeatedly (Clark, 2007). For instance, in the weeks between the 5th and the 23rd of January 2015, the chapter covered in the Social Studies lesson was titled "What do we wear and when?" In the first one of the two weeks allocated for this chapter, the story read in the class was "Gamze and her Nephew" and in the second week, it was "Kimi on the Way to School." The story titled "Gamze and her Nephew" is about Gamze's nephew who comes to visit her during the winter break, how they wear winter clothes to play snowball and have fun with their friends. This SR practice enabled children to share the language and the construct of the story, apply their knowledge and experience and use 


\section{iejee $\approx$}

such words as 'scarf,' 'cap,' 'coat,' 'jacket,' 'gloves' and 'boots,' which were used in the Social Studies lessons, in meaningful contexts (Schirmer, 2000).

(b) Relationships between the events. The sequence of events in the story must follow an order that fits in with the storyline and the illustrations must support the relationship between the events (Gerek, Karasu \& Girgin, 2019). Therefore, the stories used in the practice have been modified, pages that disrupted the flow or unity of the story were taken out and the sequence and relationships of the events were restored.

(c) Relationships between the story and the illustrations. There needs to be an explicit connection between the text and the illustrations in the stories used in SR practices so that the children can use and share the visual clues when they have difficulty in listening comprehension (Girgin, 2013; Machado, 2007). Therefore, while modifying the storybooks, it was ensured that the text and the illustration on the same page matched one another. For instance, on the second page of the story "Gülenay Out for a Trip to the Countryside", read between the 11th and the 22nd of May, 2015, Gülenay can be seen picking mushrooms and putting them in her hat, while her dog barks at a tortoise. And the text on the same page reads: "We should not crush the mushrooms. Let's pick the big ones first. There you go. I don't want anything to happen to my new hat." To establish the connection between the text and the illustration, a subscript was inserted into the illustration, which read, "Gülenay came to the countryside with her dog. She picked mushrooms. She put them into her hat. Her dog barked at the tortoise."

(d) Readability of the text. Children's understanding of the read-aloud depends on such features of the text as the theme, the children's experiences concerning the theme and the events in the story, vocabulary range, sentence structure, the length of sentences and the variety of vocabulary items (Karasu, Girgin \& Uzuner, 2013; Moody, 2006). Accordingly, the readability of the texts used in this study has been adjusted before SR to the language and knowledge level of Tan. As Tan's language skills improved, the level of difficulty of the language used in the stories was also observed to increase gradually in the academic year during this process. For instance, in the picture on the first page of the story "Cemile Learns to Swim" read between the 15th and the 19th of September, 2014 as part of the chapter titled "Holiday", Cemile and her parents are seen at the seaside with other people sitting on the beach. The original text on the page and the modified text can be seen below.

Sample 1.

The original text on the page:

"Great! We are going to the seaside," shouted, Cemile. She was about to go to the beach with her parents.
December 2020, Volume 13, Issue 2, 241-253

They had spent the previous day by the seaside, too. They had enjoyed the sea, the sun and the warm sands.

\section{Modified text:}

Cemile and her parents came to the seaside during the holiday.

In the picture on the second page of the story "Yasemin at the Baloon Fest" which was read towards the end of the academic year, as part of the chapter titled "Youth and Sports Day" between the 25th and the 29th of May 2015, it is seen that some children are holding balloons, Yasemin and her friends are releasing their balloons and the balloons are flying away. The original text on the page and the modified text is given in Sample 2 below.

\begin{abstract}
Sample 2.
The original text on the page:

It was an exciting day for all the children. Everyone gathered in the football pitch behind Yasemin's house. Yasemin could not miss this assembly. Each child had a flying balloon. They tied a label with their names and adresses to the balloons. Yasemin tied the label with her name and address to her balloon, as well. She said, "You have a nice trip," and released the balloon. Balloons in all colors started ascending towards the sky. Children returned to their homes in anticipation. They all wondered who would find their balloon.
\end{abstract}

\section{Modified Text:}

Yasemin and Gizmo went to the park. Children were holding balloons of various colors. They all released the balloons. They were very excited.

A seen in Samples 1 and 2, the text in the book consisted of complex and compound sentences, adjective and noun clauses and abstract nouns. Therefore, the text was reduced and abstract concepts were replaced for Tan to understand what he listened to. The modified text of the story used at the beginning of the term (Sample 1) can be seen to consist of a single sentence and contain nouns that Tan used frequently. The modified text of the story used towards the end of the term (Sample 2), however, consists of four sentences. These are sentences with a verb as a predicate and, in the sentence, there are adjectives and adverbs associated with the nouns and the verb. Based on this change, Tan can be said to have shown improvement in his listening comprehension skills through the academic year.

\section{How was SR implemented?}

Stages of implementation for every page in SR are presented below as (1) reading of the story and the child's retelling it (2) direction of narration and question-answer strategy.

\section{Reading of the story and the child's retelling it}

Reading starts with showing the cover page of the book to the child. The teacher points out to the name 
of the book, reads it aloud and dwells on the meaning of the name. The teacher then asks questions about the characters and the events depicted on the cover page and asks Tan to predict the events in the story. After talking about the cover page, the teacher reads the first page of the book, asks Tan what he has understood and prompts him to retell what he has understood. When Tan fails to retell the story, the teachers reads the text on the same page again.

Episodes 1 and 2 display the stages of the activity concerning the story titled "Autumn," read between the 17th and the 21st of November, 2014

\section{Episode 1.}

Teacher shows the cover of the book and says, "Today, you and I are going to read a story. The name of the book is Atakan Goes to the Playground," and points at the name of the book on the cover page. The teacher asks, "So what is the name of the book?" Tan replies, "Atakan Goes to the Playground." The teacher asks "Who is Atakan?" Tan, pointing at the picture on the cover of the book replies, "Atakan is name of child." The teacher points at the picture on the cover page of the book and asks "Who does Atakan go to the playground with?" Tan says, "His dog goes." The teacher responds by saying, "Yes, Atakan goes to the playground with his dog," and thus expands Tan's reply... While opening the first page, the teacher says, "Now, I am going to read. Listen carefully." Without showing the picture, the teacher reads the sentence, "Atakan, his mother and Comar go to the playground. Atakan holds his mother's hand." Asking the question "What do you make of this?" the teacher makes Tan tell her what he understands. Tan fails to respond. So the teacher says, "Listen carefully. I am going to read it once again," and reads the text on the page again and asks "What happened?" Tan says, "His dog goes to the playground." The teacher asks "What then?" and wants Tan to go on narrating the story....

As seen in Episode 1, the teacher expands Tan's replies and encourages him to keep telling the story through promts such as "What happened later?" and "Think about it," without offering clues.

\section{Directing narration and question-answer strategy}

The teacher listens to Tan's narration, acknowledges what he says, expands the response, and through questions and answers on what he has not talked about, checks his understanding, and directs the narration. After the narration, she asks questions regarding the causal relationships between the events, encourages inferencing and predicting while giving Tan time to think about his responses. If Tan's response is accurate she acknowledges his success, if not, she simplifies the structure of the quesiton and helps Tan to come up with an answer by offering clues. (Episode 2).

\section{Episode 2.}

. The teacher asks the question "What will Atakan do in the playground?" before she moves on to the next page. Tan replies by saying, "He will play." Teacher says, "Let's see what he does," and reads the sentences on the second page: Atakan and Comar play in the sandbox. His mother sits and reads. She asks "What do you make of this?" Tan says, "Atakan is playing." The teacher asks "What does Atakan play with?" Tan cannot answer the question. Teacher shows him the picture on the page and by pointing at the sand, says, "Look at what he plays with." Tan responds by saying "He plays sand." Teacher says "Well-done," writes the word "sand" on the board and asks Tan to read it..

As seen in Episode 2, words that Tan sees for the first time or fails to understand were written on the board, read aloud and explained, which offered him clues as to the print form of the word. It was observed that Tan tried to narrate the text with short sentences and could not answer some of the questions. Table 2 displays sample cases in which Atakan understood and answered the questions, and had difficulty in doing so during the SR practice of the story titled "Atakan Goes to the Playground."

As seen in Table 2, Tan managed to answer the questions with simple question words or which required palpable events as answers, but had difficulty understanding and answering questions which required interpreting events as a whole, estbalishing relationships and making predictions.

\section{How were $S R$ practices and writing activities integrated?}

In order to provide writing experience after the SR practices, Tan was given task cards in the first 4 days of the week, and the last days of the weeks were devoted to freewriting as follow-up acitvities.

Task cards are leaflets on which the sentences on each page of the storybook, read aloud by the teacher, are

\section{Table 2}

Kinds of Questions Tan Understood and Answered, and Those He Had Difficulty Doing so

\begin{tabular}{|c|c|c|c|}
\hline \multicolumn{2}{|c|}{ Questions Tan Understood and Answered } & \multicolumn{2}{|c|}{ Questions Tan had Difficulty Answering } \\
\hline Question & Sample & Question & Sample \\
\hline What & What is Atakan doing? & with whom/what & What is Atakan playing with? \\
\hline Who & Who is in the park? & why & Why is Atakan playing alone? \\
\hline Where & Where are the children? & when & When are the kids going home? \\
\hline Why & Why did Atakan go to the park? & $\begin{array}{c}\text { from whom/where } \\
\text { how }\end{array}$ & $\begin{array}{l}\text { Where are the kids coming from? } \\
\text { How did the kids build the tower? }\end{array}$ \\
\hline
\end{tabular}


Table 3

Number of Task Cards and Number of Words Used in FreeWriting

\begin{tabular}{|c|c|c|c|c|}
\hline \multirow{3}{*}{ Date } & \multirow{3}{*}{ Story Book } & \multicolumn{3}{|c|}{ Follow-up Activity } \\
\hline & & \multirow{2}{*}{$\begin{array}{c}\text { Task Card } \\
\text { (Day/Number) }\end{array}$} & \multicolumn{2}{|c|}{ FreeWriting } \\
\hline & & & $\mathrm{TNW}^{*}$ & TWO* \\
\hline 15-19 September 2014 & Cemile Learns to Swim & First 4 days/10 & 1 & - \\
\hline $\begin{array}{l}22 \text { September-03 } \\
\text { October } 2014\end{array}$ & $\begin{array}{l}\text { Cemile Goes to School } \\
\text { Atakan Starts School }\end{array}$ & $\begin{array}{l}\text { First } 4 \text { days } / 10 \\
\text { First } 4 \text { days/11 }\end{array}$ & $\begin{array}{l}1 \\
2\end{array}$ & -- \\
\hline 06-17 October 2014 & $\begin{array}{l}\text { Gülenay and the Little Duck } \\
\text { Yasemin in the Patisserie }\end{array}$ & $\begin{array}{l}\text { First } 4 \text { days } / 10 \\
\text { First } 4 \text { days/11 }\end{array}$ & $\begin{array}{l}2 \\
2\end{array}$ & $\begin{array}{l}1 \\
1\end{array}$ \\
\hline 20-24 October 2014 & Atakan Stays with his Grandma & First 4 days/12 & 2 & 1 \\
\hline 27-31 October 2014 & Long Live the Republic & First 3 days/10 & NA & NA \\
\hline 03-14 November 2014 & $\begin{array}{l}\text { Gülenay and the Little Puppy } \\
\text { Gülenay and the Little Pony }\end{array}$ & $\begin{array}{l}\text { First } 4 \text { days } / 10 \\
\text { First } 4 \text { days } / 10\end{array}$ & $\begin{array}{l}2 \\
3\end{array}$ & $\begin{array}{l}1 \\
1\end{array}$ \\
\hline 17-21 November 2014 & Atakan Goes to the Park & First 4 days/12 & 3 & 1 \\
\hline $\begin{array}{l}24 \text { November -05 } \\
\text { December } 2014\end{array}$ & $\begin{array}{l}\text { Cemile Wears her New Boots } \\
\text { Sleepyhead Kimi }\end{array}$ & $\begin{array}{l}\text { First } 4 \text { days } / 12 \\
\text { First } 4 \text { days/11 }\end{array}$ & $\begin{array}{l}2 \\
2\end{array}$ & $\begin{array}{l}1 \\
1\end{array}$ \\
\hline 08-12 December 2014 & Kimi Who Doesn'† Like Bathing & First 4 days/11 & 3 & 1 \\
\hline 15-26 December 2014 & $\begin{array}{l}\text { Curious Kimi } \\
\text { Ayben at the Circus }\end{array}$ & $\begin{array}{l}\text { First } 4 \text { days } / 12 \\
\text { First } 4 \text { days } / 12\end{array}$ & $\begin{array}{l}3 \\
\text { NA }\end{array}$ & $\stackrel{2}{N A}$ \\
\hline 29 December 2014-02 January 2015 & The Christmas Tree & First 3 days/10 & 3 & 2 \\
\hline 05-23 January 2015 & $\begin{array}{l}\text { Gamze and her Nephew } \\
\text { Kimi on the Way to School }\end{array}$ & $\begin{array}{l}\text { First } 4 \text { days } / 12 \\
\text { First } 4 \text { days/11 }\end{array}$ & $\begin{array}{l}3 \\
4\end{array}$ & $\begin{array}{l}2 \\
2\end{array}$ \\
\hline 09-13 February 2015 & Gamze at her New House & First 4 days/12 & 4 & 2 \\
\hline 16-20 February 2015 & Snowstorm & First 4 days/12 & 3 & 3 \\
\hline 23 February -06 March 2015 & $\begin{array}{l}\text { Gamze and her New Dog } \\
\text { Hande and her Dog on the Train }\end{array}$ & $\begin{array}{l}\text { First } 4 \text { days } / 1 \\
\text { First } 4 \text { days } / 13\end{array}$ & $\begin{array}{c}\text { NA } \\
4\end{array}$ & $\begin{array}{c}\text { NA } \\
2\end{array}$ \\
\hline 09-13 March 2015 & Yasemin and her Little Visitor & First 4 days/13 & 4 & 3 \\
\hline 16-27 March 2015 & $\begin{array}{l}\text { Gamze by the Lake } \\
\text { Yasemin and Karbeyaz }\end{array}$ & $\begin{array}{l}\text { First } 4 \text { days } / 13 \\
\text { First } 4 \text { days } / 14\end{array}$ & $\begin{array}{l}5 \\
3\end{array}$ & $\begin{array}{l}2 \\
2\end{array}$ \\
\hline 30 March-03 April 2015 & Elif at the Farm & First 4 days/13 & 4 & 4 \\
\hline 06-17 April 2015 & $\begin{array}{l}\text { Gamze and her Kite } \\
\text { Gamze in the Garden }\end{array}$ & $\begin{array}{l}\text { First } 4 \text { days } / 14 \\
\text { First } 4 \text { days } / 14\end{array}$ & $\begin{array}{c}4 \\
\text { NA }\end{array}$ & $\begin{array}{c}3 \\
\text { NA }\end{array}$ \\
\hline 20-24 April 2015 & Cemile Loves her Friend Dearly & First 4 days/14 & 5 & 3 \\
\hline 27 April-08 May 2015 & $\begin{array}{c}\text { Elif Cooks Pizza } \\
\text { Atakan Goes to the Supermarket }\end{array}$ & $\begin{array}{l}\text { First } 4 \text { days } / 14 \\
\text { First } 4 \text { days } / 14\end{array}$ & $\begin{array}{l}4 \\
5\end{array}$ & $\begin{array}{l}3 \\
4\end{array}$ \\
\hline 11-22 May 2015 & $\begin{array}{l}\text { Yasemin at the Camp } \\
\text { Gülenay out for a trip to the Countryside }\end{array}$ & $\begin{array}{l}\text { First } 4 \text { days } / 14 \\
\text { First } 4 \text { days } / 12\end{array}$ & $\begin{array}{l}7 \\
5\end{array}$ & $\begin{array}{l}5 \\
4\end{array}$ \\
\hline 25-29 May 2015 & Yasemin in the Balloon Fest & First 4 days/14 & 4 & 4 \\
\hline 01-05 June 2015 & Cemile Won't Share her Toys & First 4 days/14 & 5 & 4 \\
\hline 08-12 June 2015 & Cemile Goes on a Holiday & First 4 days/14 & NA & NA \\
\hline 11-22 May 2015 & $\begin{array}{c}\text { Yasemin at the Camp } \\
\text { Gülenay out for a trip to the Countryside }\end{array}$ & $\begin{array}{l}\text { First } 4 \text { days } / 14 \\
\text { First } 4 \text { days } / 12\end{array}$ & $\begin{array}{l}7 \\
5\end{array}$ & $\begin{array}{l}5 \\
4\end{array}$ \\
\hline 25-29 May 2015 & Yasemin in the Balloon Fest & First 4 days/14 & 4 & 4 \\
\hline 01-05 June 2015 & Cemile Won't Share her Toys & First 4 days/14 & 5 & 4 \\
\hline 08-12 June 2015 & Cemile Goes on a Holiday & First 4 days/14 & NA & NA \\
\hline
\end{tabular}

${ }^{*}$ TNW=Total Number of Words, TWC=Total Number of Words Written Correctly, NA= Not Available

written. Tan was asked to read the sentences on these task cards, write them down in his own notebook and draw a picture of the events in the sentences. In instances when he failed to read, the teacher pointed out to the first letter of the word to offer a clue, and after reading the sentence, asked Tan "What happened?" to check his understanding one more time. Tan, then wrote the sentence in his notebook, drew the picture and the teacher checked his understanding for the last time. When it was finished, Tan wrote the date on the back of the task card he studied on and moved on to the next task card. The task cards were thus completed after story reading in four days. Tan was not given a task card on the 5th day and was given 
a freewriting task. In freewriting tasks, the teacher showed him the book and asked him which event he wanted to write about, expecting Tan to pick one of the events in the book. Tan drew a picture of the event of his own choice and wrote sentences about what happened under the picture. He was not offered any visual clues during this writing activity. Table 3 shows the number of task cards used in the followup activities and the number of words Tan used to describe the picture in his freewriting efforts.

\section{Task cards prepared with regard to the story}

The number of cards depends on the events in the story and the number of pages read on a specific day. The average number of cards concerning a story ranges between 10 and 14 (Table 3). On top of each card is the name of the story-written in red, and below are one or two sentences about one of the events in the story-written in black. The font size was 14 and Vertical Basic Alphabet letters were used. A quick look at the features of the task cards that help structuring meaning will reveal that (a) the sentences read aloud by the teacher and listened to by the child are written on the task cards, (b) the sentences are about palpable events that yield to illustrations, and that (c) similar to the text of the story, the level of difficulty of the language used in the task cards gradually increases as the language skills of the child improves. For instance, the third page and the relevant task card of the story titled "Cemile Goes to School" read as part of the chapter "Our School" between the 22nd of September and the 3rd of October, 2014, reads "Cemile's mother held her hand. They went to school together." The task card concerning the fifth page of the story titled "Atakan Goes to the Supermarket" read as part of the chapter on "Shopping" betwen the 26th of April and the 8th of May, 2015, reads "Atakan went to the toys stand. His mother was not with him. Atakan was lost. The security officer approached him."

\section{Writing Related Experience}

It can be observed through features of freewriting concerning the structuring of meaning that (a) the child draws a picture of en event of his choice and writes his remarks under this picture, (b) the freewriting products go through a revision process where the child and the teacher interact on a one-on-one basis, and (c) revised, corrected and filed writing products are read out in one-on-one sessions involving the child and the teacher. During the study, on the days other than those Tan didn't show up for school, a total of 31 freewriting products have been obtained (Table 3). In these activities, Tan tried to write a single word as the name of the character in the story at the beginning of the semester and the number of words and the ones he wrote correctly increased towards the end of the semester. The sentences, however, turned out to be the same as the ones he wrote on the task cards in the first 4 days of the week. For instance, after listening to the story titled "Yasemin at the Camp" read as part of the chapter on "The Plants around Us" towards the end of the semester between the 11th and the 15th of May, 2015, for 5 days and doing the task cards activities, Tan wanted to write about the events on a page which reads "Yasemin, her mother, father, Pınar and Gizmo went out to the garden. They looked at the squirrels in the tree." He wrote six of the words in the sentence correctly (Yasemin, her mother, father, Pınar, Gizmo), and two words contain errors. One of them has an incorrect word spelling (garden), the other has a tense error (went out). The words he wrote correctly are the names of the characters in the story that have been repeated frequently. The same sentence was also written on one of the task cards about the story.

\section{Discussion}

Optimization of the benefits of SR depends on the features of the materials to be used in the practices, and the instructional strategies employed to meet the child's needs. It can be observed in this study that the themes in the storybooks used in SR practices matched the subject matter of the Social Studies course; that the same story was modified and read multiple times during the week; that a variety of instructional strategies were used and follow-up activities were employed to offer writing experiences. An empirical study conducted with children with hearing loss at pre-school level (Pataki, Metz, \& Pakulski, 2014) concludes that storybooks which are parallel in terms of theme with the subject matter covered in class facilitate interaction and participation in SR practices. The similarity between the theme in the storybook and the subject covered in class also enables practice and repetition of new vocabulary and sentence structures in a variety of contexts (Girgin, 2013; Otaiba, 2004).

Children are exposed to natural opportunities to learn new vocabulary in their daily lives. Children with hearing loss, however, cannot benefit from these natural opportunities due to their limited vocabulary and need various modifications and a lot of repetition of language structures to ensure the development of their vocabulary range (Clark, 2007). The parallelism between the themes of the stories used in SR practices and the content of the Social Stuides course, the multiple readings of the story, and the integrated use of reading and writing skills in the follow-up activities contribute to the lexical and syntactic development of children with hearing loss who use spoken language (Strasser et al., 2013). Multiple readings also enable these children to recognize, use and control reading 
strategies, and internalize the features of written language by reinforcing the improvemnet of higher cognitive skills (Stewart, Bonkowski, \& Bennet, 1990).

This study was conducted in the Primary 1st Grade where decoding skills are taught formally. In Turkey, the Phonic Based Sentence Method (PBSM) is used to equip children with these decoding skills. The first literacy program prepared by the Ministry of National Education (MoNE) also recommends listening activities in addition to PBSM. Children with hearing loss who have latency in their language skills usually have difficulty in the listening comprehension of these materials prepared for their hearing peers. Therefore, instead of the listening scripts in the MEB course books, modified storybooks were used in this study.

Both stylistic features of the materials used in SR practices and their features regarding the structuring of meaning play significant roles in children's understanding of the story they listen to. The same page illustration of the events in the text, the sequence of illustrations to demonstrate the relationship between these events, and the appropriety of the readability level of the text to the language skills of the child all facilitate listening comprehension and structuring of meaning. This kind of reading materials also increases motivation which has a prominent role in the structuring of meaning (Machado, 2007). The language in the storybooks used in this study has been modified to match the language skills of the child with hearing loss so as to assist the development of the child's skills in listening comprehension and structuring meaning.

Another determinant in the success of SR practices is the way these practices are carried out. Kaderavek and Justice (2002) point our that it is necessary to (a) enable children to share their thoughts and feelings concerning the events in the story, (b) encourage participation, (c) reinforce the development of linguistic skills, and (d) increase the children's interest in the books while carrying out SR practices. During this study, the teacher read the story to the child and then asked the child to retell the story. The child's retelling the story not only facilitates listening comprehension skills but also enables the assessment of these skills (Machado, 2007). Retelling the story was followed by the direction of the narration, expansion of the child's response, sharing the events in the story through questions and answers, inviting the child to talk about his thoughts and feelings about the story, correction of mistakes and encouraging praticipation. Throughout the implementation of these strategies, Tan tried to retell the story, answered some simple questions and had diffciulty in understanding and answering some others. His failure to answer certain questions may be due to the reason that he didn't understand the question, that he didn't know how to respond to the question or that he didn't know the answer. By implication, supporting the development of listening, comprehension and speaking skills make the use of reading strategies easier and these strategies in turn facilitate the development og language skills (Schirmer, 2000).

It is pointed out in other researches investigating SR practices (Williams, \& McLean, 1997; Gioia, 2001) that the teacher's attitude and the strategies applied during implementation affect the child's participation, and extra attention needs to be paid to these two issues to increase active participation and motivation. Directing narration, furthering child's participation, supporting the development of lingusitic skills, asking questions and sharing answers have a positive impact on the motivation of the child with hearing loss. Use of these strategies facilitate oral participation skills of the child and improves vocabulary range, morphosyntactic skills and comprehension skills (DesJardin et al., 2014; Kaderavek \& Justice, 2002).

SR practices consist of instructional practices that support the literacy skills of children with hearing loss who experience latency in their language skills through 'natural environments' and 'natural forms of interaction' during intervention programs (Kaderavek \& Justice, 2002). SR not only facilitates the achievement of language and literacy targets but also creates opportunities to implement strategies to improve these skills in children with hearing loss. Vocabulary range, for instance, is an important factor in the development of literacy skills. In this study, new vocabulary items for Tan were accentuated in their natural context and their meaning and written form were demonstrated. Sharing new vocabulary items in meaningful contexts for the children in this way makes their use and retension easier (Akay, 2015; Trussell \& Easterbrooks, 2014).

Literacy experiences are directly related to the establishment of the letter-sound relationship of the language, and the development of syntactic, semantic and pragmatic skills (Schirmer, 2000). A follow-up activity is the kind of post-lesson exercise that offers experiences related to the language and literacy and enables the use of the language used in the classroom in a variety of contexts. Follow-up activities after SR need to support the child in the integration of reading and writing skills using the language and information obtained from the story that the child listens to (Pakulski \& Kadarevek, 2004). Existing literature on SR predominantly focuses on the pre-school period, and therefore, does not relate to writing activities. In this study, which was conducted 
in the Primary 1st Grade, task cards were used systematically in the first four days in the follow-up activities and Tan was asked to read and rewrite what is written in the cards and picture the events. The last school day was devoted to freewriting sessions aiming at the integration of his writing skills with his listening, speaking and comprehension skills. Task cards and the writing activities carried out on the last day of the week at school played an important role in the structuring of meaning, and the integration of listening, speaking, reading and writing skills (Girgin, 2013).

An examination of the task cards used throughout the Primary 1st Grade in this study will reveal that sentence structures have gradually become more complex, and the number and variety of words have increased towards the end of the term. These sentences, as specimens of the language used in the shared stories, can also be observed in the writing products of the last day of the week. Findings show that, in the first few months, Tan wrote only a couple of words in the freewriting activities and these words were usually misspelt. This might suggest that the development of desired skills took a slow start. However, this was probably due to the gradually increasing complexity of the shared stories, the child's inexperience in expressing events in writing, and his need to practice. The writing products that Tan has come up with after SR practices towards the end of the academic year display characteristics of 'invented writing.' In the invented writing stage, children manage to write some words that they frequently see and make attempts at establishing letter-sound relationships while writing the words disregarding any formal rules (Hofslundsengen, Gustafsson \& Hagtvet, 2019). In this study, Tan had difficulty coining a sentence expressing his thoughts on the event he wanted to write about and tried to remember and use the words written on the task cards. This is why writing products do not display the characteristics of 'conventional writing.' In his attempts at writing, Tan tried to use his alphabetic knowledge in writing activities and tried to write down certain words that he recalled by bringing letters together. Writing process products obtained towards the end of the semester can therefore be considered as evidence of increasing motivation to write and development of print knowledge (Piasta \& Wagner, 2010).

\section{Limitations and Recommendations}

This study was carried out in an educational environment in which early intervention principles were applied within the framework of the auditoryoral approach. The subject of the study was a child with hearing loss who has been attending SR practices since the pre-school period and is currently in the Primary 1st Grade. The data collected is restricted to a time span of one year. The benefits to be obtained from SR practices in the educational environment depend largely on the implementation, assessment and utilization of the features of the materials, instructional strategies and follow-up activities with an eye towards the language and knowledge levels of the child as well as the modification of these so as to fit in with the child's needs. Therefore, it is important to assess the child's vocabulary range and skills in listening, retelling, establishing relationships, predicting, and understanding and answering questions in the educational environment. The implementation process has to be closely monitored. The language used in the readings, the variety of questions, and the follow-up activities have to be continuously redesigned to match the improvement in these skills. It can be suggested for future studies to look into the contribution of SR practices to literacy skills through longitudinal studies, and assess the impact of SR practices on writing products through qualitative and quantitative studies.

\section{Conclusion}

Although cochlear implants alleviate the latency in language skills, a child with hearing loss still has difficulty developing language skills in certain aspects and needs support to structure meaning. SR practices are known to play a significant role in overcoming these challenges. Based on the findings of this research, it can be safely claimed that (a) the modifications on the storybooks, (b) the instructional strategies used and (c) the follow-up activities that offer writing experience are important factors in reaping full benefits of SR practices.

\section{References}

Akay, E. (2015). Investigating affordances of resource room activities for mainstreamed hearingimpaired primary school students' Turkish language classes. Journal of Education \& Special Education Technology, 1(1), 1-14.

Blachowicz, C. L. Z., \& Fisher, P. J. (2007). Best practices in vocabulary instruction. In L. B. Gambrell, L. M. Morrow and M. Pressley (Eds.), Best practices in literacy instruction (3rd ed.), (pp. 178-203). The Guildford Press.

Clark, M. (2007). A practical guide to quality interaction with children who have a hearing loss. Plural Publishing. 
Creswell, J. W. (2005). Educational research: Planning, conducting, and evaluating quantitative and qualitative research (2nd ed.). Pearson Education.

DesJardin, J. L., Doll, E. R., Stika, C. J., Eisenberg, L. S., Johnson, K. J., Ganguly, D. H., et al. (2014). Parental support for language development during joint book reading for young children with hearing loss. Communication Disorders Quarterly, 35(3), 167-181

Druten-Frietman, L. V., Strating, H., Denessen, E., \& Verhoeven, L. (2016). Interactive storybookbased intervention effects on kindergartners language development. Journal of Early Intervention, 38(4), 212-229.

Evans, M. A., \& Saint-Aubin, J. (2013). Vocabulary acquisition without adult explanations in repeated shared book reading: an eye movement study. Journal of Educational Psychology, 105(3), 596-608.

Falk, J. L., Di Perri, K. A., Howerton-Fox, A., \& Jezik, C. (2020). Implications of a sight word intervention for deaf students. American Annals of the Deaf, 164(5), 592-607.

Gerek, A., Karasu, H. P., \& Girgin, U. (2019). Examination of the preparation process of serial storybooks used in shared reading activity with children with hearing loss. Cumhuriyet International Journal of Education, 8(3), 712-734.

Gioia, B. (2001). The emergent language and literacy experiences of three deaf preschoolers. International Journal of Disability, Development and Education, 48(4), 411-428.

Girgin, Ü. (2013). Teacher strategies in shared reading for children with hearing impairement. Eurasian Journal of Educational Research, 53, 249-268.

Hofslundsengen, H., Gustafsson, J. E., \& Hagtvet, B. E. (2019). Contributions of the home literacy environment and underlying language skills to preschool invented writing. Scandinavian Journal of Educational Research, 63(5), 653-669.

Hudson, M. E., \& Test, D. W. (2011). Evaluating the evidence base of shared story reading to promote literacy for students with extensive support needs. Research \& Practice for Person with Severe Disabilities, 36(1-2), 34-45.
Justice, L. M. (2006). Creating language-rich preschool classroom environments. Teaching Exceptional Children, 37, 36-44.

Kaderavek, J., \& Justice, L. M. (2002). Shared storybook reading as an intervention context. American Journal of Speech-Language Pathology, 11(4), 395-406.

Karasu, H. P., Girgin, U., \& Uzuner, Y. (2013). Informal reading inventory. Nobel Akademik Yayincilik.

Lederberg, A. R., Miller, E. M., Easterbrooks, S.R., \& McDonald-Connor, C. (2014). Foundations for literacy: an early literacy intervention for deaf and hard-of hearing children. Journal of Deaf Studies and Deaf Education, 19(4), 438-455.

Lonigan, C. J., Purpura, D. J.,Wilson, S. B., Walker, P. M., \& Clancy-Menchetti, J. (2013). Evaluating the components of an emergent literacy intervention for preschool children at risk for reading difficulties. Journal of Experimental Child Psychology, 114, 111-130.

Machado, J. M. (2007). Early childhood experiences in language arts early literacy (8th ed.). Thomson Delmar Learning.

Miller, W. H. (2005). Improving early literacy: Strategies and activities for struggling students (K-3). Jossey-Bass.

Moody, A. K. (2006). Using assistive technology to support literacy development in young children with disabilities. In L.M. Justice (Ed.), Clinical approaches to emergent literacy intervention (pp. 71- 97). Plural Publishing.

Otaiba, S.A. (2004). Weaving moral elements and researched-based reading practices in inclusive classrooms using shared book reading techniques. Early Child Development and Care, 174(6), 575-589.

Pakulski, L. A., \& Kaderavek, J. N. (2004). Facilitating literacy using experience books: A case study of two children with hearing loss. Communication Disorders Quarterly, 25(4), 179-188.

Pataki, K. W., Metz, A. E., \& Pakulski, L. (2014). The effect of thematically related play on engagement in storybook reading in children with hearing loss. Journal of Early Childhood Literacy, 14(2), 240-264. 
Piasta, S. B., \& Wagner, R. K. (2010). Developing emergent literacy skills: A meta-analysis of alphabet learning and instruction. Reading Research Quarterly, 45, 8-38.

Piasta, S. B., Justice, L. M., McGinty, A. S., \& Kaderavek, J. N. (2012). Increasing young children's contact with print during shared reading: Longitudinal effects on literacy achievement. Child development, 83(3), 810-820.

Schirmer, B. R. (2000). Language and literacy development in children who are deaf (2nd ed.). Allyn and Bacon, Inc.

Spencer, E.J., Goldstein, H., \& Kaminski, R. (2012). Teaching vocabulary in storybooks: embedding explicit vocabulary instruction for young children. Young Exeptional Children, 15(1), 18-32.

Stewart, D., Bonkowski, N., \& Bennett, D. (1990). Considerations and implications when reading stories to young deaf children, Occasional Paper No. 113. East Lansing, Ml: Michigan State University, College of Education, Institute For Research on Teaching.

Strasser, K., Larrain, A., \& Lissi, M. R. (2013). Effects of storybook reading style on comprehension: The role of word elaboration and coherence questions. Early Education and Development, 24(5), 616-639.

Trussell, J. W., \& Easterbrooks, S. R. (2014). The effect of enhanced storybook interaction on signing deaf children's vocabulary. Journal of Deaf Studies and Deaf Education, 19(3), 319-332.

Trussell, J. W. (2018). Interactive storybook reading instruction for preschoolers who are deaf and hard of hearing: A multiple probe across behaviors analysis. Language, Speech, and Hearing Services in Schools, 49, 922-937.

Werfel, K. L., Lund, E., \& Schuele, M. (2015). Print knowledge of preschool children with hearing loss. Communication Disorders Quarterly, 36(2), 107-111.

Williams, C. L., \& McLean, M. M. (1997). Young deaf children's response to picture book reading in a preschool setting. Research in the Teaching of English, 31(3), 337-366.

Yin, R. K. (2009). Case study research: Design and methods (4th ed). Sage Pbc.
Zucker, T. A., Justice, L. M., Piasta, S. B., \& Kaderavek, J. N. (2010). Preschool teachers' literal and inferential questions and childrens' responses during wholeclass shared reading. Early Childhood Research Quarterly, 25, 65-83. 